\title{
PENGEMBANGAN KAPASITAS MANAJEMEN SEKOLAH DALAM MEMBANGUN PEMAHAMAN VISI DAN MISI
}

\author{
Dwi Sukaningtyas, Djam'an Satori, dan Udin Syaefuddin Sa'ud \\ Pascasarjana Universitas Pendidikan Indonesia Bandung \\ Email: sukaningtyas.dwi@gmail.com/dwi.suka@yahoo.com
}

\begin{abstract}
Abstrak: Visi dan misi merupakan tujuan akhir yang menjadi pedoman bagi aktivitas sekolah dan dapat difungsikan sebagai dasar kekuatan layanan bermutu ke peserta didik. Namun, banyak sekolah hanya menjadikan visi dan misi sekadar ada, tetapi tidak menjadi pedoman yang bermakna bagi penyelenggaraan pendidikan. Penelitian ini bertujuan untuk mendeskripsikan dan menganalisis kapasitas manajemen sekolah dalam membangun pemahaman visi misi. Penelitian ini menggunakan pendekatan kualitatif dengan studi kasus. Metode pengumpulan data yang digunakan adalah wawancara, observasi lapangan, dan studi dokumen/artifact. Uji keabsahan data dilakukan dengan kredibilitas, transferabilitas, dependabilitas, dan konfirmabilitas. Hasil penelitian menunjukkan bahwa sekolah yang membangun pemahaman visi misi berdasarkan nilai-nilai luhur pendiri lebih memiliki dasar kuat untuk pengembangansekolah.
\end{abstract}

Kata kunci: visi, misi, kapasitas manajemen sekolah

\section{DEVELOPING THE CAPACITY OF THE SCHOOL MANAGEMENT IN ENHANCING THE UNDERSTANDING OF VISION AND MISSION}

\begin{abstract}
Vision and mission constitute the ultimate goaland serve as guidelines for school activities and as the strong foundationsfor providingqualified service to learners. However, in many schools, the vision mission just existswithout being considered as meaningful guidelines for the implementation of education. This research aims to describe and analyze the capacity of the school management in building up understanding of the vision and mission. It used a qualitative approach with case studies. Data collection methods included interviews, observation, and study of the documents/artifacts. Data validation was done through credibility, transferability, dependability, and confirmability. The results show that schools which establish vision and mission based on noble values of the founders have strongerfoundations for school development.
\end{abstract}

Key word: vision, mission, the capacity of school management

\section{PENDAHULUAN}

Tahun 2005, secara nasional, delapan Standar Nasional Pendidikan diberlakukan. Sejak itu, semua sekolah mencantumkan visi dan misi sebagai tujuan akhir penyelenggaraan pendidikan. Di dalam salinan lampiran Peraturan Menteri Pendidikan Nasional RI Nomor 19 (2007) tentang Standar Pengelolaan Pendidikan oleh Satuan Pendidikan Dasar dan Menengah, disebutkan bahwa sekolah dalam perencanaan programnya merumuskan dan menetapkan visi, misi, dan tujuan sekolah serta pengembangannya (salinan, 2007).

Visi merupakan tujuan akhir sekolah yang dicapai dalam jangka panjang. Sedangkan misi merupakan tujuan jangka menengah yang selanjutnya biasa dirinci dalam tujuan sekolah yang harus dicapai setiap tahun operasional sekolah. Beberapa penelitian tentang esensi visi dan misi pada organisasi atau lembaga pendidikan telah dilakukan, antara lain sebagai berikut. Bahwa visi yang lebih kuat terkait dengan kinerja organisasi yang lebih kuat (Kantabutra dan Avery, 2010:39). Bahwa efek perbaikan sekolah yang bermakna dan perubahan organisasi berpusat pada pengembangan bersama visi dan misi untuk kemajuan (Gurley, dkk., 2014:1). Ketika pimpinan atau manajer mampu bekerjasama dengan tim berdasar visi bersama, maka pekerjaan mereka akan mencerminkan tingkat harmoni dan transparansi (Ahanhanzo, Odushin, dan Adelakoun, 2006:20). Bahwa visi sekolah adalah salah satu dari tiga elemen/ bagian esensi yang harus ada untuk meningkatkan sekolah. Dua elemen lainnya adalah membangun 
kapasitas dan kepemimpinan (Southern Regional Education Board/SREB, 2010:ii).

Beberapa hasil penelitian menyebutkan seperti berikut ini. Bahwa visi, misi, tujuan, dan nilai-nilai yang diharapkan dapat tergambar pada praktik harian peserta didik ternyata hanya sebatas untuk diingat saja. Seharusnya visi, misi, tujuan, dan nilai-nilai yang dibangun melalui praktik yang baik menjadi kunci peningkatan mutu sekolah (Gurley dkk, 2014:3). Praktik harian yang dimaksud adalah dapat diterapkan secara terus menerus, sehingga pada akhirnya dapat meningkatkan prestasi sekolah dan pembelajaran peserta didik.Penelitian lainnya menerapkan visi dalam lingkup yang lebih luas, yaitu visi pendidikan di suatu Negara. Bahwa kebijakan yang tidak kompatibel menyebabkan pemerintah kurang dukungan secara politik (SREB, 2010:ii). Sementara itu, membangun visi bersama untuk pendidikan mencerminkan tingkat transparansi yang bermanfaat untuk semua pihak (Ahanhanzo, Odushin, dan Adelakoun, 2006:20).

Berdasar beberapa penelitian di atas, bahwa visi dan misi merupakan pedoman yangmendasari seluruh program atau bagian di sekolah/lembaga/ organisasi. Esensi visi dan misi diharapkan juga dapat tergambar pada aktivitas setiap individu di sekolah, lembaga,dan organisasi karena perbaikan atau pengembangan yang dilakukan berpusat padanya.

Pada kenyataannya, banyak sekolah hanya menjadikan visi sekolah sekadar "ada", tetapi tidak menjadi pedoman yang bermakna bagi penyelenggaraan pendidikan. Hal selanjutnya yang terjadi, sekolah hanya sekadar melaksanakan rutinitas tanpa tahu makna dari pelaksanaannya, karena masih banyak ditemui, hasil pendidikan yang ada semua serba "instan", peserta didik hanya belajar sekedar untuk mendapatkan nilai, pendidik mengajar hanya sebatas materi yang perlu diajarkan saja tanpa memaknainya. Hal tersebut tidak sejalan dengan apa yang tersirat dalam UU Pendidikan Nasional No. 20 tahun 2003, pasal 1 dan 3, yang antara lain menyebutkan lebih rinci fungsi dan tujuan pendidikan "seutuhnya".

Apa yang menyebabkan masalah terurai di atas terjadi? Tujuan pendidikan dan pembelajaran yang tercermin di dalam visi-misi sekolah belum tercapai sepenuhnya. Sama halnya pencapaian kemampuan penguasaan pengetahuan dan sikap yang bermasalah. Beberapa penelitian sebelumnya juga berasumsi bahwa kemungkinan hal tersebut terjadi karena kapasitas sekolah yang belum dapat diberdayakan maksimal.

Diasumsikan bahwa "Sekolah yang tidak mempunyai kapasitas atau kemampuan yang cukup jelas akan kesulitan melakukan berbagai upaya perbaikan yang berkelanjutan secara efektif." Ketiga aspek kapasitas sekolah yang terjadi masih dalam taraf implementasi, belum mempunyai arah kebijakan program yang jelas. Kapasitas yang dipunyai sekolah tidak diarahkan untuk hal yang unggul dan fokus pada tujuan tertentu (Sumintono, 2013). Sementara itu, di dalam studi pendahuluan penelitiannya, mengasumsikan bahwa “... sekolah mengalami banyak masalah kapasitas manajemen sekolah, khususnya terkait dengan ketidakberfungsian peran dan fungsi pendidik dan tenaga kependidikan dalam menyelesaikan tugas-tugasnya dan memecahkan permasalahan yang dihadapi sekolah" (Triatna, 2014:1).

Pengembangan kapasitas sekolah telah dilakukan untuk beberapa kebutuhan, antara lain, pemanfaatan kapasitas sekolah semaksimal mungkin untuk keberhasilan pelaksanaan manajemen berbasis sekolah (MBS). Kapasitas sekolah yang meliputi empat aspek berkaitan dengan pelaksanaan manajemen berbasis sekolah dalam rangka desentralisasi pendidikan pada jenjang pendidikan dasar. Tujuan studi ini untuk memperoleh data dan informasi mengenai peta kapasitas sekolah yang terkait dengan empat aspek yaitu: anggaran sekolah, sumber daya manusia dan sarana prasarana sekolah, manajemen sekolah, serta partisipasi orangtua siswa (Koster, 2011). Pada penelitian lainnya menyebutkan pengembangan kapasitas sekolah untuk pencapaian sekolah unggul atau untuk meningkatkan mutu sekolah (Sumintono, 2013; Triatna, 2014).

Visi misi merupakan tujuan unik yang melingkupi aktivitas dan dapat dimanfaatkan sebagai kekuatan mutu layanan organisasi. Bagaimana sekolah mengembangkan kapasitas manajemendalam membangun pemahaman visi misinya? Pertanyaan tersebut menjadi dasar pembahasan dalam penelitian ini.

\section{METODE}

Penelitian ini menggunakan pendekatan kualitatifjenis studi kasus, multikasus karena situs penelitian ada dua. Metode pengumpulan data kualitatif dilakukan melalui wawancara, observasi, studi dokumen dan artifact. Persiapan untuk pendekatan ini dilakukan dengan menyiapkan 
kerangka penelitian yang berisikan fokus kajian, metode pengumpulan data yang digunakan, dan partisipan yang terlibat. Kerangka penelitian dirinci ke kisi-kisi instrumen sesuai aspek yang diteliti. Selanjutnya, kisi-kisi instrumen dirinci dalam bentuk panduan untuk semua metode pengumpulan data. Masing-masing terdapat panduan untuk wawancara, observasi, dan studi dokumen/ artifact.

Proses pengumpulan data, pengolahan, dan display hasil pendekatan kualitatif dilakukan lebih kurang selama delapan bulan. Rangkaian tahap ini dimaksudkan untuk meneliti kondisi kapasitas manajemen sekolah. Data lengkap tentang kondisi kapasitas manajemen sekolah dievaluasi dan dianalisis sebagai dasar untuk mengetahui pola pengembangan kapasitas manajemen sekolah dalam membangun visi dan misi.

Observasi dilakukan untuk mengetahui aktivitas rutin yang dilakukan warga sekolah terkait dengan program-program yang dimaksudkan untuk membangun visi misi. Selain itu juga dilakukan pengamatan pada pertemuanpertemuan pembahasan dan penetapan kebijakan, atau pembinaan pendidik dan tenaga kependidikan. Wawancara dilakukan dengan berpedoman pada kisi-kisi instrumen literature review berupa pertanyaan-pertanyaan dengan jawaban terbuka. Wawancara dilakukan dengan satu partisipan atau lebih dalam bentuk focus group discussion (FGD). FGD dilakukan pada sesi perancangan program dan evaluasi, karena pada tahap tersebut banyak dilakukan kerja tim. Selain itu, juga dilakukan wawancara tidak terstruktur atau informal dengan teknik "conversational"/perbincangan harian. Partisipan yang terlibat pada wawancara dipilih melalui snowball method. Partisipan ditentukan sebagai key informants, selanjutnya dari mereka dipilih partisipan selanjutnya. Konteks penelitian ini terkait nilai dasar lembaga yang biasanya dibangun awal oleh para pendiri sekolah. Sehubungan dengan konteks tersebut, dipilih key informants untuk setiap sekolah adalah pendiri atau ketua yayasan dan kepala sekolah. Partisipan lain yang kemungkinan terlibat adalah para pendidik dan tenaga kependidikan, peserta didik/ calon peserta didik, dan orang tua/calon orang tua. Masing-masing terlibat sesuai perannya dalam penyelenggaraan sekolah. Pemilihan dengan metode ini diharapkan dapat menghasilkan ukuran sampel yang cukup untuk mendeskripsikan kondisi dalam berbagai perspektif. Peneliti merupakan instrumen utama (keyinstrument). Peneliti juga mengambil peran sebagai observer partisipan.

Studi dokumen sekolah dilakukan dengan mengumpulkan dokumen-dokumen sekolah yang relevan dengan konteks penelitian. Dokumendokumen tersebut berupa antara lain rencana pengembangan sekolah (RPS), rencana kerja tahunan, dokumen aktivitas sekolah, dokumen pembelajaran (perencanaan pengajaran, agenda pelaksanaan, serta rencana dan hasil penilaian), rencana anggaran sekolah, dan sebagainya. Studi artifact dilakukan dengan melakukan dokumentasi dalam bentuk gambar. Pengumpulannya dimaksudkan untuk menghubungkan keberadaannya berdasar manfaatnya dalam proses pengembangan kapasitas manajemen sekolah. Seluruh proses pengumpulan data dilakukan dengan tata cara yang berpedoman pada prosedur pengambilan data kualitatif.

Data penelitian diuji keabsahannya dengan derajat kepercayaan (credibility), keteralihan (transferability), kebergantungan (dependability), dan kepastian (confirmability). Berdasarkan pengumpulan data, didapatkan kondisi rasional yang terjadi di lapangan. Deskripsi kondisi rasional tersebut merupakan hasil credibility (validitas internal) dengan teknik member checking dan triangulation. Member checking merupakan hasil interpretasi dan simpulan data peneliti yang disampaikan pada partisipan untuk dimintai persetujuan. Triangulasi dilakukan dengan cara membandingkan dan mengecek tingkat kepercayaan suatu informasi yang diperoleh dari beberapa sumber (partisipan yang terlibat dalam wawancara formal dan informal) juga metode pengumpulan data (seperti wawancara, observasi, dan strudi dokumen/artifact). Hasil pengumpulan data selanjutnya dianalisis secara kualitatif, analisis kasus tunggal dan multikasus.

\section{HASIL DAN PEMBAHASAN}

Penelitian dilakukan untuk menjawab pertanyaan bagaimana sekolah mengembangkan kapasitas manajemen dalam membangun pemahaman visi misinya?

Pengumpulan data dilakukan melalui wawancara mendalam dan harian, observasi, serta studi dokumen/artifact dilakukan pada dua lokasi sekolah, yaitu SMA Nasima (sekolah A) dan SMA Islam Sultan Agung 1 (sekolah B) Semarang. Pada masing-masing lokasi, partisipan wawancara yang terlibat antara lain: pengurus/ 
manajemen lembaga, kepala sekolah, wakil kepala sekolah, dan pendidik. Selanjutnya, hasil wawancara antarpartisipan ditriangulasi sumber, kemudian ditriangulasi juga dengan metode pengumpulan data lainnya seperti observasi dan studi dokumen/artifact, sehingga diperoleh refleksi atau pemaknaan data yang relatif sama.

Fokus kajian atas pertanyaan penelitian terdiri atas dua aspek yang diteliti, yaitu karakteristik dan indikator pencapaian visi misi. Hasil pemaknaan pada kedua lokasi sesuai kode aspek disajikan pada Tabel 1.

Persamaan kedua lembaga/sekolah dalam menyusun pernyataan visi dan misi berdasarkan filosofi yang dianut lembaga. Sekolah B menganut nilai-nilai agama Islam, maka dasar visi-misi diambil dari Al Quran dan Hadist. Sementara itu, sekolah A menganut nilai-nilai Nasionalis dan Agama (Islam), maka dasar visi-misi didapat oleh pendiri dari perjalanan panjang bangsa/negara yang dipengaruhi budaya lokal dan perkembangan pendidikan di Indonesia yang dikawinkan dengan nilai-nilai agama Islam yang dianut dalam perkembangan agama Islam di Indonesia.

Visi merupakan tujuan akhir sekolah, tujuan jangka panjang organisasi.Visi telah dianggap sebagai komponen penting dari kepemimpinan efektif selama lebih dari 20 tahun (Bush, 2015). Kedua sekolah menganggap visi sebagai pernyataan penting, sehingga nilai-nilai luhur (filosofi) yang dianut oleh lembaga menjadi dasar dalam menyusun pernyataan visi. Tidak hanya visi, pernyataan misi kedua sekolah juga disusun berdasar nilai-nilai tersebut. Misi yang baik dipahami sebagai dasar tujuan layanan organisasi. Misilah yang membedakan bentuk layanan antarorganisasi. Misi merupakan pernyataan yang mendeskripsikan layanan terhadap pelanggan.Bahwa setiap pernyataan khusus (visi/misi) untuk organisasi/sekolah harus berarti sesuatu yang istimewa/unik/spesifik untuk mereka yakini (Bainbridge, 2007).

Tidak cukup hanya sesuatu yang istimewa, sistem pendidikan manusia harus dibangun dengan dasar yang kuat. Pendidikan tidak hanya terakumulasi berdasar pengetahuan, untuk yang terbaik hal tersebut tidak lengkap. Dasar yang lengkap diperoleh dari kitab suci, bahwa wahyu Allah merupakan dasar dari semua pengetahuan (Flurry, 2007). Bahwa visi berasal atau muncul dari kedekatan manusia dengan Sang Pencipta, untuk mengetahui dan merenungkan firman-Nya, untuk menjadi apapun yang Sang Pencipta kehendaki (Barna, 2009; Mario, 2005). Pada kondisi empirik yang peneliti temui, oleh kedua lembaga, visi dan misi sekolah telah disusun berdasar nilainilai yang dalam kitab suci yang dianut. Pada sekolah B, kalimat visi “... membentuk generasi khaira ummah" merupakan pernyataan yang kembali pada pemikiran awal pendiri di tahun 1950an, yang mengambil dasar pernyataan visi dari surat AL-Quran yaitu surat Ali Imron ayat 110. Di sekolah A, salah satu dasar pernyataan visi dan misi adalah hadist Rasulullah yang berbunyi: "Didiklah anak-anak (keturunanmu) karena mereka itu akan menghadapi suatu zaman bukan seperti zamanmu."

Pernyataan visi dan misi pada kedua sekolah disusun awal dengan melibatkan pihak lembaga. Bahkan salah satunya menyatakan 'menitipkan' visi kepada pihak sekolah untuk dapat dimaknai bersama dan dilaksanakan. Pihak yang terlibat dalam penyusunan pernyataan visi dan misi pada lembaga swasta, umumnya melibatkan pihak lembaga/yayasan dan sekolah. Pihak lembaga berkepentingan untuk menitipkan granddesign yang memuat filosofi dasar penyusunan visi dan misi. Sementara pihak sekolah berkewajiban untuk dapat menerjemahkan dalam kalimat pernyataan. Pada intinya makna dari kalimat pernyataan visi dan misi sesuai dengan granddesign dari lembaga.

Pernyataan visi-misi sebaiknya disusun secara tim atau bersama, yaitu orang-orang yang berkepentingan akan melaksanakannya. Hal ini bertujuan agar orang-orang tersebut memahami alasan perancangan pernyataan visi-misi, karena merupakan visi-misi bersama (Bainbridge, 2007). Bahwa efek perbaikan sekolah yang bermanfaat dan bermakna untuk semua pihak berpusat pada pengembangan/membangun pemahaman visi dan misi bersama. Saat visi dan misi tidak disusun bersama oleh pihak lembaga dan sekolah, maka ada konsekuensi yang muncul, seperti, kalimat pernyataan kurang mudah dipahami, atau belum ada kesamaan dalam memaknainya (Gurley dkk, 2014; Ahanhanzo, Odushin, dan Adelakoun, 2006).

Pada sekolah A dan B, rata-rata para pendidik/tenaga kependidikan kurang/tidak hafal pernyataan visi dan misi. Namun saat diminta untuk memaknainya, mereka berusaha dan dapat mengartikannya dalam bahasa yang hampir sama. Rata-rata para pendidik/tenaga kependidikan lebih 
Tabel 1. Kondisi Empirik berdasar Triangulasi Hasil Pengumpulan Data Wawancara

\begin{tabular}{|c|c|}
\hline \multicolumn{2}{|c|}{ RASIONAL/KONDISI EMPIRIK - HASIL PENGUMPULAN DATA } \\
\hline SEKOLAH A & SEKOLAH B \\
\hline $\begin{array}{ll}\text { Kode Aspek } & : \text { RMa01.01.01 } \\
\text { Aspek } & \text { : Karakteristik pencapaian visi dan misi }\end{array}$ & \\
\hline $\begin{array}{l}\text { - Penyusunan pernyataan visi dan misi (terutama visi) } \\
\text { didasari pada keprihatinan pendiri yang merasakan } \\
\text { dampak dari pendidikan di masa lalu yang dirasa } \\
\text { kurang bisa membekali anak-anak bangsa dengan } \\
\text { kualitas kompetensi keilmuan dan keterampilan } \\
\text { hidup, akhlaq mulia, serta pembentukan karakter dan } \\
\text { jati diri sebagai insan Indonesia. } \\
\text { - Pernyataan visi murni disusun oleh badan pendiri, } \\
\text { sedangkan pernyataan misi telah melalui penyusunan } \\
\text { ulang di tahun 2008, disusun bersama pihak lembaga } \\
\text { dan sekolah. } \\
\text { - Rata-rata pendidik/tenaga kependidikan tidak/kurang } \\
\text { hafal kalimat pernyataan visi dan misi secara } \\
\text { lengkap. } \\
\text { - Rata-rata pendidik/tenaga kependidikan dapat } \\
\text { menyebutkan kalimat inti dari pernyataan visi/misi, } \\
\text { dan mampu memaknainya. } \\
\text { - Ada dokumen yang menyebutkan tentang makna } \\
\text { pernyataan visi dan misi. } \\
\text { Dokumen tersebut telah diberikan kepada } \\
\text { pendidik/tenaga kependidikan (buku saku } \\
\text { kepegawaian). } \\
\text { Dokumen tersebut belum menjadi sarana 'pengingat' } \\
\text { bagi pendidik/tenaga kependidikan. }\end{array}$ & $\begin{array}{l}\text { - Penyusunan pernyataan visi dan misi (terutama } \\
\text { visi) didasari khitah pendiri pada tahun 50-an. } \\
\text { Grand design pernyataan visi (intinya) disusun } \\
\text { dan dirumuskan pertama kali oleh tim lembaga, } \\
\text { selanjutnya pada kalimatnya (visi) dan pernyataan } \\
\text { misi, tim pendidik (kepala sekolah) ikut terlibat. } \\
\text { Keterlibatan tim pendidik juga termasuk dalam } \\
\text { penyusunan karakteristik/indikator pencapaian, } \\
\text { yang selanjutnya dikembangkan sebagai rencana } \\
\text { strategis sekolah untuk jangka waktu minimal '15 } \\
\text { tahun'. } \\
\text { - Rata-rata pendidik/tenaga kependidikan tidak/ } \\
\text { kurang hafal kalimat pernyataan visi dan misi } \\
\text { secara lengkap. } \\
\text { - Rata-rata pendidik/tenaga kependidikan dapat } \\
\text { menyebutkan kalimat inti dari pernyataan visi, } \\
\text { dan mampu memaknainya. } \\
\text { - Sementara kalimat misi, mereka juga } \\
\text { tidak/kurang hafal. Namun, sebagai pendidik, } \\
\text { mereka sedang berproses menuju arah tersebut. } \\
\text { - Makna visi dan misi tidak terdapat dalam } \\
\text { dokumen sekolah. }\end{array}$ \\
\hline
\end{tabular}

Kode Aspek : RMa01.01.02

Aspek : Indikator pencapaian visi dan misi

- Karakteristik yang ada di pernyataan visi dan misi belum dirinci ke dalam indikator-indikator pencapaian, tetapi detail karakteristik telah ada dalam bentuk diagram alur. Sementara rinci misi juga belum dituliskan runtut ke tujuan sekolah.

- Pernyataan visi dan misi, juga tujuan tertulis lengkap pada dokumen sekolah (RKS/RKAS).Selain dokumen, artifactpernyataan visi dan misi ada di hampir semua ruang pada lingkungan sekolah.

- Pemahaman terhadap karakteristik visi misi pernah diberikan dalam satu forum khusus. Namun hanya bersifat tentatif, baru dilakukan satu/dua kali, belum dilakukan secara berkala/terus menerus.

- Karakteristik yang ada di pernyataan visi telah dirinci ke dalam indikator-indikator pencapaian. Sementara rinci misi dituliskan sebagai tujuan sekolah. Karakteristik visi tersebut selanjutnya diterjemahkan lebih ke dalam beberapa program sekolah.

- Pernyataan visi dan misi, juga tujuan tertulis lengkap pada dokumen sekolah (RKS/ RKAS), termasuk karakteristiknya. Namun, selain dokumen, artifact visi dan misi hampir tidak ditemukan di lingkungan sekolah.

- Pemahaman terhadap karakteristik visi misi tidak secara spesifik diberikan dalam forum untuk para pendidik dan tenaga kependidikan. Forum pertemuan internal yang digagas lembaga lebih inti pada pengembangan profesional pendidik/tenaga kependidikan.

- Indikator pencapaian visi dan misi tertulis pada dokumen sekolah. Di dalam dokumen RKS/RKAS tersebut indikator pencapaian yang dievaluasi ulang setiap 4 tahun (sesuai pergantian pimpinan unit sekolah).

mudah menyebutkan dan memaknai visi, karena pernyataannya berupa satu kalimat. Makna visi dan misi sekolah A telah terdokumentasi pada buku saku pendidik/tenaga kependidikan dan buku pribadi peserta didik. Sementara itu, makna visi dan misi sekolah B tidak disebutkan secara jelas pada dokumen sekolah. Makna visi dan misi sekolah dibutuhkan untuk dipahami agar dapat 
diketahui karakteristiknya. Karakteristik inilah yang akan ditunjukkan dalam praktik keseharian pendidik/tenaga kependidikan dan peserta didik (warga sekolah). Bahwa karakteristik visi dan misi diharapkan dapat tergambar pada praktik harian warga sekolah (Gurley, dkk., 2014).

Karakteristik pernyataan visi dan misi sekolah A telah digambarkan dalam diagram alur 'Pendidikan Karakter Nasima'(Kode artifact: ArA-01) yang terdiri dari empat bagian tapi merupakan satu kesatuan. Diagram alur ini memang baru ada sekitar dua tahun lalu, karena dalam perkembangan sekolah, lembaga penyelenggara merasa perlu memahamkan ulang karakteristik visi dan misi sekolah. Saat pengumpulan data dilakukan, sekolah A masih dalam proses merinci karakteristik visi dan misi ke indikator-indikator pencapaian, karena sebelumnya indikator pencapaian belum terdokumentasi. Karakteristik visi sekolah $\mathrm{B}$, dirinci dalam bentuk indikator pencapaian visi. Karakteristik yang terkandung di dalam visi terkait dengan kata-kata indikator membentuk generasi khaira ummah. Indikator tersebut adalah terbentuknya generasi muda yang memiliki sifat kader generasi khaira ummah, yaitu adanya kompetensi : beriman, berilmu, beramal, dan berakhlak mulia (seperti di dalam dokumen RKS/RKAS). Sementara itu, karakteristik misi belum disebutkan dalam dokumen. Apakah karakteristik visi dan misi sekolah yang ada termasuk yang efektif?

Berpedoman pada pengertian serta pengambilan simpulan dari beberapa pendapat (Wheelen dan Hunger, 2012; Khalifa, 2011; Kantabutra dan Avery, 2010; Kantabutra dan Vimolratana, 2009; Kantabutra, 2010) tentang karakteristik visi dan misi yang efektif untuk sekolah sebagai berikut.

1) Karakteristik visi yang efektif, yaitu: a) ringkas, sederhana, realistis, dan jelas; dari bahasa pernyataan secara keseluruhan; b) fokus dan unik; dari isinya yang mengarah pada tujuan akhir organisasi; c) menantang, menginspirasi, dan berorientasi masa depan; dari kata-kata yang mengandung makna ungkapan semangat dan pandangan jauh ke depan.

2) Karakteristik misi yang efektif, yaitu: a) ringkas, jelas, realistis, dan komunikatif; dari bahasa pernyataan; b) fokus dan tepat; dari isinya yang mengarah pada tujuan layanan organisasi; c) menantang, memotivasi, dan fleksibel/relevan; dari kata-kata yang mengandung makna ungkapan semangat yang diperlukan anggota organisasi untuk dapat melaksanakan.

Apabila memperhatikan kalimat pernyataan visi pada sekolah A, "Membimbing Insan Indonesia Berilmu dan Berakhlaq Al Karimah", cukup ringkas dan mudah diingat/sederhana. Namun pernyataan tersebut mengandung pemaknaan yang cukup mendalam. Sebagai contoh, kata pertama 'membimbing' terkait dengan semua individu yang ada di sekolah yang bertugas untuk 'membimbing'. Penyusun tidak menggunakan kata mendidik atau mengajar, karena arti kata dasar dari membimbing lebih pada pimpin, asuh, atau tuntun (Kamus Besar Bahasa Indonesia, 2016), yang dapat bermakna memberi pengasuhan seperti orang tua pada anaknya, menuntun untuk memberi petunjuk atau memberi pelajaran, dan makna lainnya. Pemaknaan visi untuk mendapatkan karakteristiknya yang tepat perlu didukung dengan pemberian pemahaman yang tepat.

Pada pernyataan misi sekolah A terdapat tiga kalimat yang cukup ringkas, dan hampir sama dengan kalimat pernyataan misi, membutuhkan pemaknaan yang cukup mendalam. Secara umum apabila melihat kalimatnya masih bermakna cukup luas, sehingga fokusnya kurang, walau sebenarnya telah dapat menggambarkan bentuk layanan yang diberikan. Seperti pada kalimat pertama, "Menyelenggarakan pendidikan yang berkualitas" yang dapat dimaknai sekolah akan memberikan layanan yang 'berkualitas/bermutu' di semua bagian.

Sementara pada kalimat pernyataan visi sekolah B, "Sebagai Lembaga Pendidikan Menengah Umum Islam terkemuka dalam pendidikan, pendalaman, dan penghayatan nilai-nilai Islami, dan penguasaan dasar-dasar ilmu pengetahuan dan teknologi (iptek) untuk mempersiapkan kader-kader generasi khaira ummah" merupakan kalimat yang cukup panjang untuk dapat diingat. Pemaknaannya cukup jelas secara awam, tetapi masih ada kata yang perlu dimaknai lebih dalam. Pernyataan misi pada sekolah B terdapat tujuh kalimat. Beberapa kalimat juga cukup panjang, sehingga cukup sulit untuk diingat, tetapi pemaknaannya cukup jelas. Kalimat-kalimat juga telah fokus pada bentuk layanan yang diberikan, misalnya kalimat keenam "Menciptakan budaya sekolah Islami”.

Persamaan makna kalimat visi pada kedua sekolah telah memuat apa yang disyaratkan Undang-Undang Pendidikan Nasional No. 20 tahun 
2003 tentang pendidikan 'seutuhnya'. Kedua kalimat visi telah memberikan karakteristik bahwa kalimat tersebut disusun atas dasar pondasi nilainilai agama yang kuat, sesuai dengan keinginan penyelenggara pendidikan. Bahwa poin pertama dari tujuh kunci sukses pendidikan adalah "build a solid spiritual foundation" (Flurry, 2007:30; Barna, 2009). Nilai-nilai ini juga yang dalam rinci indikatornya digunakan untuk mengembangkan karakter melalui program-program sekolah.

Inti dari efektivitas karakteristik tersebut adalah dapat dipahami dengan mudah dan diyakini oleh orang-orang untuk dapat dilaksanakan (Bainbridge, 2007). Kedua sekolah memberikan pemahaman karakteristik visi dan misi melalui forum bersama. Ada yang khusus untuk pendidik/ tenaga kependidikan, orang tua, maupun peserta didik. Namun, kekurangan yang tampak adalah forum pemberian pemahaman belum dilakukan secara berkala atau terus menerus. Selain itu, forum yang diselenggarakan terkadang bukan merupakan forum khusus yang diperuntukkan doktrinasi/sosialisasi karakteristik visi dan misi, tetapi menjadi bagian dari forum pertemuan dengan tujuan lainnya seperti pembinaan atau pengembangan profesional sumber daya manusia. Pemahaman yang diberikan kepada warga sekolah tidak cukup sebatas visi dan misi. Pemahaman atau penjelasan yang sama juga dibutuhkan untuk seluruh warga sekolah tentang tujuan yang akan dicapai. Selain visi dan misi, sekolah B telah merinci misinya ke tujuan sekolah. Rinci tersebut saling terkait dalam kalimat misi. Sementara tujuan sekolah A belum merupakan rinci yang runtut dari misi.

Definisi tujuan berbeda dari visi dan misi, pernyataan tujuan menguraikan dengan tepat apa tingkat kinerja yang harus dicapai dalam domain yang dipilih (misalnya, belajar peserta didik, atau pengembangan profesional pendidik) dan langkah-langkah apa yang harus diambil, oleh siapa, untuk mencapai tujuan.Tujuan tersebut semestinya nyata dapat diraih, artinya pernyataan tujuan merupakan pernyataan operasional yang memungkinkan akan dapat dijalankan. Tujuan sekolah yang jelas dan fokus akan lebih mudah dipahami oleh seluruh komunitas sekolah (Gurley dkk, 2014; Hoy \& Miskel, 2008). Oleh karena itu, tujuan sekolah akan mudah dinyatakan apabila karakteristik yang efektif dari visi dan misi diketahui.
Pembahasan mengenai kondisi sekolah dalam mengembangkan kapasitasnya untuk membangun visi dan misi, tidak hanya dibahas pada aspek yang telah disajikan. Bahwa di dalam membangun visi dan misi diawali dengan meletakkan pondasi visi dan misi yang disesuaikan dengan nilai-nilai dasar/luhur yang dianut pendiri/ pencetus lembaga. Pondasi atau dasar tersebut dituangkan dalam pernyataan visi, misi, dan tujuan sekolah. Susunan kalimat dalam pernyataan visi, misi, dan tujuan yang kurang sesuai dengan karakteristik visi dan misi yang efektif, memerlukan bentuk pemahaman yang kontinu pada semua warga sekolah.

Pemahaman tentang karakteristik visi misi diberikan kepada seluruh warga sekolah melalui berbagai metode, diantaranya doktrinasi dan sosialisasi pada forum pertemuan. Upaya pemahaman juga membutuhkan perulangan penyampaian, sehingga visi misi yang telah dirinci di dalam tujuan sekolah dan program betul-betul dipahami dan menjadi cerminan pembiasaan keseharian seluruh warga sekolah. Upaya membangun visi misi dengan memahami karakteristiknya juga dilakukan melalui budaya sekolah.Sekolah A menanamkannya melalui artifact sekolah seperti cerita, lambang/simbol, lagu, foto dokumentasi, dan sebagainya. Sementara itu, sekolah B memiliki program Budaya Sekolah Islami (BuSI) yang digunakan sebagai sarana memahamkan rinci visi misi dalam cerminan aktivitas harian sekolah.

Pengembangan kapasitas manajemen sekolah pada akhirnya dimaksudkan untuk peningkatan mutu layanan sekolah. Mutu layanan sekolah diukur berdasarkan ketercapaian visi dan misi. Karena pada intinya mutu layanan sekolah adalah mutu kinerja organisasi yang digambarkan melalui kinerja manajemennya. Sementara itu, beberapa hasil penelitian menyebutkan bahwa terdapat hubungan yang signifikan antara budaya organisasi dengan kinerja manajemen (Dizik, 2016; Ovidiu-Iliuta, 2014; Lunenburg, 2011; Mujeeb, Tahir \& Shakil, 2011), bahwa budaya yang positif atau kuat akan meningkatkan kinerja. Budaya yang positif atau budaya yang kuat memungkinkan dapat menjadi sarana untuk pengembangan kapasitas manajemen sekolah. Kedua sekolah telah menggunakannya melalui artifact dan program. Artifact dan program merupakan sarana yang dapat dipergunakan untuk menyebarkan budaya organisasi. 
Budaya organisasi dapat difungsikan untuk membangun rasa identitas bagi anggotanya. Dan melalui cerita, ritual, lambang/simbol, dan bahasa komunikasi, pembinaan budaya organisasi dapat dilakukan (Robbins \& Judge, 2013; Wibowo, 2011). Bahwa budaya yang kuat menunjukkan anggotanya untuk membangun kekompakan, loyalitas, dan komitmen organisasi. Kekuatan budaya ini berhubungan dengan kinerja yang menyangkut tiga gagasan, diantaranya yang pertama adanya rintisan tujuan (Robbins \& Judge, 2013). Pada sekolah, tujuan merupakan rinci dari visi dan misi. Sementara itu, visi dan misi dibangun dari nilai-nilai luhur yang dianut pendiri/lembaga. Sehingga dapat dikatakan budaya yang kuat dibangun oleh nilai-nilai yang dianut dan diciptakan oleh pendiri/penggagas lembaga.

\section{SIMPULAN}

Visi, misi, dan tujuan sekolah saling terkait. Pencapaian visi dan misi sekolah merupakan makna pencapaian mutu sekolah. Mutu sekolah yang diharapkan dinyatakan dalam pernyataan visi dan misi.

Hasil penelitian menunjukkan bahwa kedua sekolah yang menjadi situs telah mulai melakukan pengembangan kapasitas manajemen yang diawali dengan membangun pemahaman visi dan misi. Hal tersebut difokuskan agar arah pengembangan kapasitas manajemen dapat efektif dilakukan. Pemahaman karakteristik visi dan misi menjadi bagian penting di dalamnya. Kalimat pernyataan visi misi disusun berdasar nilai-nilai luhur yang dianut oleh pendiri/pengagas lembaga berproses dapat dimaknai dengan baik oleh seluruh warga sekolah. Pemahaman makna atau karakteristik visi misi dilakukan melalui budaya sekolah, melalui kalimat pernyataan visi-misi, simbol, slogan, cerita, ritual/rutinitas harian, bahasa komunikasi, dan sebagainya. Doktrinasi atau sosialisasi yang dilakukan secara berulang dimaksudkan agar pemahaman warga sekolah terhadap visi dan misi melekat di dalam cerminan aktivitas hariannya.

Peserta didik, pendidik, tenaga kependidikan, dan warga sekolah lainnya yang merupakan bagian dari kapasitas sekolah secara kontinu diberikan pemahaman tentang karakteristik visi dan misi yang di dalamnya terdapat nilai-nilai luhur yang dianut pendiri/lembaga. Pemahaman tentang karakteristik visi dan misi dalam upaya membangun pemahaman visi dan misi. Bahwa budaya sekolah yang kuat dibangun atas dasar nilai-nilai yang dianut dan diciptakan oleh pendiri/ penggagas lembaga. Pengembangan kapasitas manajemen sekolah memiliki dasar yang kuat apabila visi dan misi dibangun dari nilai-nilai luhur yang dianut dan diciptakan oleh pendiri/ penggagas lembaga.

\section{UCAPAN TERIMA KASIH}

Melalui artikel ini, Penulis mengucapkan terima kasih kepada para pemangku kebijakan di kedua sekolah, SMA Nasima dan SMA Islam Sultan Agung 1 Semarang, atas kesempatan dan kerjasamanya telah mengijinkan penulis melakukan penelitian dan dapat sharing informasi mengenai implikasi perkembangan konsep-konsep teori kapasitas manajemen sekolah. Pengembangan teori tentang kapasitas organisasi nonprofit, terutama untuk sekolah masih sangat minim di Indonesia. Sementara di luar Indonesia, saat sekarang sedang marak dilakukan berdasar kemajuan pemikiran ke arah pemberdayaan organisasi untuk mendukung organisasi menjadi organisasi pembelajar yang mampu beradaptasi dengan arus globalisasi dan perubahan lingkungan.

Penulis berharap kepada para pemangku kebijakan di kedua sekolah, baik yayasan, manajemen, maupun kepala sekolah dapat menerapkan berbagai strategi guna meningkatkan mutu layanannya. Mutu program akan berdampak pada mutu layanan, terutama bagi sekolah swasta yang sepanjang tahun harus terus berinovasi untuk dapat bertahan mendapatkan kepercayaan masyarakat luas. Sekolah menengah atas swasta sangat perlu mengembangkan kapasitas manajemen yang terarah. Keunikan atau kekhasan yang dimiliki masing-masing sekolah menengah atas swasta perlu dikembangkan dengan komitmen kuat sesuai visi dan misi.

\section{DAFTAR PUSTAKA}

Ahanhanzo, J., Odushin, D.E. \& Bibi-Adelakoun, A. 2006. Building a Vision for Education in Benin. Prospects, Volume 36, Iss1, hlmn 9-21.

Bainbridge, S. 2007. Creating A Vision for Your School, Moving from Purpose to Practice. London: Paul Chapman Publishing, A SAGE Publications Company.

Barna, G. 2009. The Power of Vision : Discover and Apply God's Plan for Your Life and Ministry. California, USA: Regal Books. 
Bush, T. 2015. The Problem with Vision. Editorial. Educational Management Administration \& Leadership, Vol. 43(2) 175-176.

Dizik, A. 2016. The Relationship Between Corporate Culture and Performance. The Wall Street Journal, Journal Reports: Leadership, Feb. 21, 2016. Diakses dari : http:// www.wsj.com/articles/the-relationship-between-corporate-culture-and-performance1456110320 .

Flurry, S. 2007. Education with Vision. USA: The Philadelphia Church of God.

Gurley, D. dkk. 2014. Mission, vision, values, and goals: An exploration of key organizational statements and daily practice in schools. Springer Science+ Business Media Dordrecht, Published online : 26 February 2014. [Online, 9 Oktober 2014]. Diakses dari :http://link.springer.com/ article/10.1007/s10833-014-9229-x.

Hoy, W.K. \& Miskel, C.G. 2008. Educational Administration, Theory, Research, and Practice.Eighth edition. New York, USA : The McGraw-Hill Companies, Inc.

Kamus Besar Bahasa Indonesia. [Online,19 Maret 2016]. Diakses dari: www.kbbi.web.id/ bimbing

Kantabutra, S. 2010. Vision effects: a critical gap in educational leadership research. International Journal of Educational Management, Vol. 24, Iss: 5, hlm.376-390.

Kantabutra, S. \& Avery, G.C. 2010. The Power of Vision: Statements that Resonate. Journal of Business Strategy, Vol. 31, Iss 1,hlm. 37-45.

Kantabutra, S. \& Vimolratana, P. 2009. Visionbased leadership : relationships and consequences in Thai and Australian retail stores. Asia-Pacific Journal of Business Administration, Vol. 1, Iss: 2, hlm.165-188.

Khalifa, A.S. 2011. "Three Fs for the mission statement: what's next?" Journal of Strategy and Management, Vol. 4, Iss 1,hlm. 25-43.
Koster, W. 2011. Restrukturisasi Penyelenggaraan Pendidikan: Studi Kapasitas Sekolah dalam Rangka Desentralisasi Pendidikan. [Online, 12 April 2015]. Diakses dari: https://muhammadalmustofa.wordpress. com/2011/04/03/restruk-turisasi-penyelenggaraan-pendidikan-studi-kapasitassekolah-dalam-rangka-desentralisasi-pendidikan.

Lampiran Peraturan Menteri Pendidikan Nasional Republik Indonesia Nomor 19 Tahun 2007 Tanggal 23 Mei 2007 tentang Standar Pengelolaan Pendidikan oleh Satuan Pendidikan Dasar dan Menengah.

Lunenburg, F.C. 2011. Organizational CulturePerformance Relationships: Views of Excellence and Theory Z. National Forum of Educational Administration and Supervision Journal, volume 29, number 4, hlm.1-10.

Mario. 2005. The Power of Vision. Croatia: CEO (Croatian Evangelistic Outreach).

Mujeeb E., Tahir M.M., \& Shakil A.M. 2011. Relationship between Organizational Culture and Performance Management Practices: A Case of University in Pakistan. Journal of Competitiveness, Issue 4 v3, hlm. 78-86.

Ovidiu-Iliuta, D. 2014. The Link Between Organizational Culture and Performance Management Practices : A Case of IT Companies from Romania. The Bucharest University of Economic Studies (Institute of Doctoral Studies, Business Administration), Bucharest, Romania.

Robbins, S.P. \& Judge, T.A. 2013.Organizational Behavior. Fifteenth Edition. USA : Pearson Education, Inc.

Southern Regional Education Board (SREB). 2010.The Three Essentials: Improving Schools Requires District Vision, District and State Support, and Principal Leadership. [Online, 9 Oktober 2014].Diakses dari :http://www.wallacefoundation.org/ knowledge-center/school-lead-ership/ district-policy-and-practice/Documents/ 
Three-Essentials-to-Improving-Schools. pdf.

Sumintono, B. 2013. Sekolah Unggulan: Pendekatan Pengembangan Kapasitas Sekolah. $J M P$, Volume 2 Nomor 1.

Triatna, C. 2014. Ringkasan Hasil Penelitian: Pengembangan Kapasitas Manajemen Sekolah untuk Meningkatkan Mutu Pendidikan di Sekolah, Studi Kasus di SMA Negeri 2 Kota Bandung dan SMA Negeri 2 Kota Tasikmalaya. Bandung: Program Studi Administrasi Pendidikan, Sekolah Pascasarjana, Universitas Pendidikan Indonesia.
Undang-undang Republik Indonesia Nomor 20 Tahun 2003 tentang Sistem Pendidikan Nasional.

Wheelen, T.L. \& Hunger, J.D. 2012. Strategic Management and Business Policy, Toward Global Sustainability.Thirteenth Edition. USA : Pearson Education, Inc.

Wibowo. 2011. Budaya Organisasi. Jakarta: Rajawali Pers. 